\title{
PROBABILISTIC APPROACH ON SEISMOGENIC POTENTIAL OF A FAULT
}

\author{
CHUN-JOONG CHANG \\ KHNP Central Research Institute \\ 25-1 Jang-dong, Yuseong-gu, Daejeon 305-343, Republic of Korea \\ "Corresponding author. E-mail : geochang@khnp.co.kr
}

Received August 02, 2010

Accepted for Publication March 09, 2011

Siting criteria for nuclear power plants require that faults be characterized as to their potential for generating earthquakes, or that the absence of the potential for these occurrences be demonstrated. Because the definition of active faults in Korea has been applied by the deterministic method, which depends on the numerical age of fault movement, the possibility of inherent uncertainties exists in determining the maximum earthquake from the fault sources for seismic design. In an attempt to overcome these problems this study suggests new criteria and a probabilistic quantitative diagnostic procedure that could estimate whether a fault is capable of generating earthquakes in the near future.

KEYWORDS : Active Fault, Seismogenic Potential, Maximum Earthquake, Seismic Hazard Analysis, Seismic Design

\section{INTRODUCTION}

Several Quaternary faults ${ }^{1)}$ have been found along the Ulsan fault, the Yangsan fault, and the eastern coastline on the Korean peninsula. The Yangsan fault is one of the major faults in the southeastern part of the Korean peninsula. Several research groups have found field evidence of Quaternary faulting and have suggested that the Yangsan fault is an active fault ${ }^{2)}$ based on the numerical dating of the fault movement and seismological features. As a result, the Yangsan fault has been the focus of geological, geochronological, seismological, and paleoseismological studies [1-4]. Currently about 50 sites of Quaternary faults have been identified in the southeastern part of the Korean peninsula. These faults are mostly located along the Yangsan fault, Ulsan fault and east coastline (Fig. 1).

The initial stage of the Quaternary fault study in Korea has concentrated on identification in the field and determination of the faulting age to judge whether the

\footnotetext{
1) The Quaternary faults in Korea are distributed mainly along the pre-existing major faults such as the Yangsan and Ulsan faults. The term Quaternary fault in this study means the outcrop of the fault that cut the Quaternary deposits.

2) An active fault generally means a fault at which an earthquake is likely to occur sometime in the future. In this study, the term "active fault" also includes a capable fault as defined by the regulatory guide of US NRC.
}

faults were active according to the US NRC definition. If the age of a fault is within the age range of an active fault, the fault should be considered as a seismic source, and

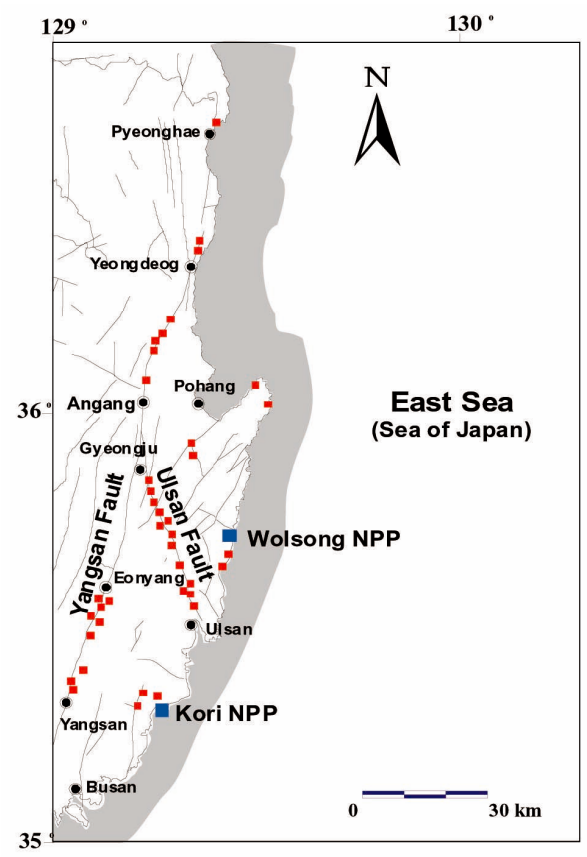

Fig. 1. Locations of the Quaternary Faults (Small Boxes) in the Southeastern Part of the Korean Peninsula 
the maximum earthquake magnitude should be evaluated from the fault parameters. Therefore, the deterministic method for assessing seismic hazard for a fault source is very sensitive to the faulting age because it is not easy to obtain suitable dating material in the field. However, inherent geological uncertainties are inevitably included, so it is necessary to consider the problem of estimating the probability that a geological feature with a set of known characteristics is active.

As mentioned above it is critical that the seismic hazard for nuclear power plants be carefully assessed since some of the Quaternary faults in Korea could be considered active faults. In terms of determining whether the faults are active there has been considerable debate among geologists and geophysicists in Korea. The definitions and criteria of capable faults that have been applied in Korea are based on both the origin and timing of the most recent movement of the faults (i.e. surface or near-surface deformation within the last 500,000 or 35,000 years). This regulation requires that seismic sources be characterized as to their potential for generating earthquakes and causing surface deformation. This study suggests a new set of criteria and quantitative diagnostic procedures that could estimate whether a fault is capable of generating earthquakes in the future.

\section{DIAGNOSTIC CRITERIA FOR ASSESSING SEISMOGENIC POTENTIAL}

Despite the extensive research work and the results so far achieved, the issue of assessing seismogenic potential has not yet been fully resolved. As mentioned above, it is not easy to define whether the faults are active by the deterministic approach. This study suggests a new probabilistic approach that can be used to assess the seismogenic potential of faults on the Korean peninsula on the basis of the US NRC technique [5]. It is expected that this method can be applied for probabilistic seismic hazard analysis on the Korean peninsula.

\subsection{Fault with a Historical Rupture}

A fault with a historical rupture is the most reliable evidence of an active fault. About ten historical earthquakes greater than MMI VIII have been reported near the Gyeongju area along the Yangsan fault. The greatest earthquake (MMI X) on the Korean peninsula occurred around Ulsan city in 1643 [6]. It resulted in the generation of a large tsunami, liquefaction along the coast, and destruction of some beacon houses. These earthquakes occurred mainly in the Gyeongju-Ulsan areas in the SE part of the Korean peninsula.

Because the Yangsan fault is considered as the most major fault with recent history of movement, paleoseismological studies have been carried out to determine the earthquake potential of the fault source based on the geologic record. This has involved extensive paleoseismological investigation along the Yangsan fault, Ulsan fault and the east coastline, which has been performed by trench investigations. The initial stage of paleoseismological studies was carried out at the Eonyang-Tongdosa area, which was the site of the first discovery of the Quaternary fault on the Korean peninsula. The results of the trench survey of this site showed geological and geomorphological evidence of the Quaternary reactivation with an average vertical slip rate of about $0.02-0.07 \mathrm{~mm} / \mathrm{yr}$ in this area based on paleo-events. The results of paleoseismological study at the Yugye-ri site near Pohang city showed an average vertical slip rate of about $0.04-0.05 \mathrm{~mm} / \mathrm{yr}$ with the last age of faulting estimated at 1314 B.P. by radio carbon dating $[1,7]$.

In order to verify a historical rupture, it is necessary to further study the relationship between the historical earthquakes and the Quaternary faults with reference to fault activity in Korea. Evidence from such studies will provide a strong indication of whether a fault is seismogenic and will be the most important criterion for assessing the seismogenic potential of the fault.

\subsection{Spatial Association between Fault and Earthquake}

A fault can be considered as seismogenic if it has been causally associated with historical earthquakes of large magnitude or shows unequivocal evidence of repeated late Quaternary displacement. There exist uncertainties in the seismogenic potential of any fault. This uncertainty is expressed by the probability that the fault is seismogenic and will be less than 1.0. However, it can be difficult to associate older historical events with a particular fault because of uncertainties in the epicenter location. Sometimes even instrumentally located events are not easily associated with known faults. Such uncertainty in determining the seismogenic potential of a fault is expressed by the probability that a fault is seismogenic, with 1.0 being the greatest.

Because it is important to genetically clarify the relationship between a fault and an earthquake, this study uses a range of assessments for an idealized linear fault and observed seismicity to illustrate the notion of a spatial association of seismicity with a fault (Fig. 2). For example, if a fault is spatially associated with several strong instrumental and historical earthquakes greater than M 5, it would have a high potential for being seismogenic. If a fault displays a clear spatial association with earthquakes aligned along its entire length and large earthquakes of greater than M 5 have occurred, it would be assessed to be associated with seismicity with a probability of 1.0 (Fig. 2C). On the other hand, if the spatial association of a fault is one of small earthquakes that show no tendency to align themselves along the linear fault, the fault would be assessed to be associated 
with seismicity with a probability of only 0.1 (Fig. 2A).

As shown in Fig. 1, the Quaternary faults are distributed along the Yangsan and Ulsan faults in the southeastern part of the Korea. Whereas these major faults are known as faults that moved in Tertiary time, recent studies suggest that these faults have also experienced displacement in Quaternary time. Lee et al. $[8,9]$ suggested that the Yangsan fault is seismologically active on the basis of the high historical seismicity around the Gyeongju area as well as high microearthquake activities along the Yangsan fault system. In order to investigate the relationship between the seismicity and the faults in the southeastern part of the Korean peninsula, the faults and epicenters of historical and instrumental earthquakes are plotted in Fig. 3. The historical and instrumental earthquake data for Korea have been compiled and analyzed by many authors. The earthquake data used here were obtained from the historical earthquake catalog by K. Lee (unpublished), which runs from 2 A.D. to 1984 and includes all instrumental earthquakes. Total 295 earthquakes, including 169 historical and 126 instrumental events, were examined for this study.

A number of epicenters are clustered in the vicinity of Gyeongju and the eastern part of the Ulsan fault. However, there appears no close correlation between the faults and epicenters. The epicenters show almost a scattering pattern, which does not reflect any specific geological structures. In this case the geological structures may be assessed to be associated with seismicity with a probability of less than 0.2 .

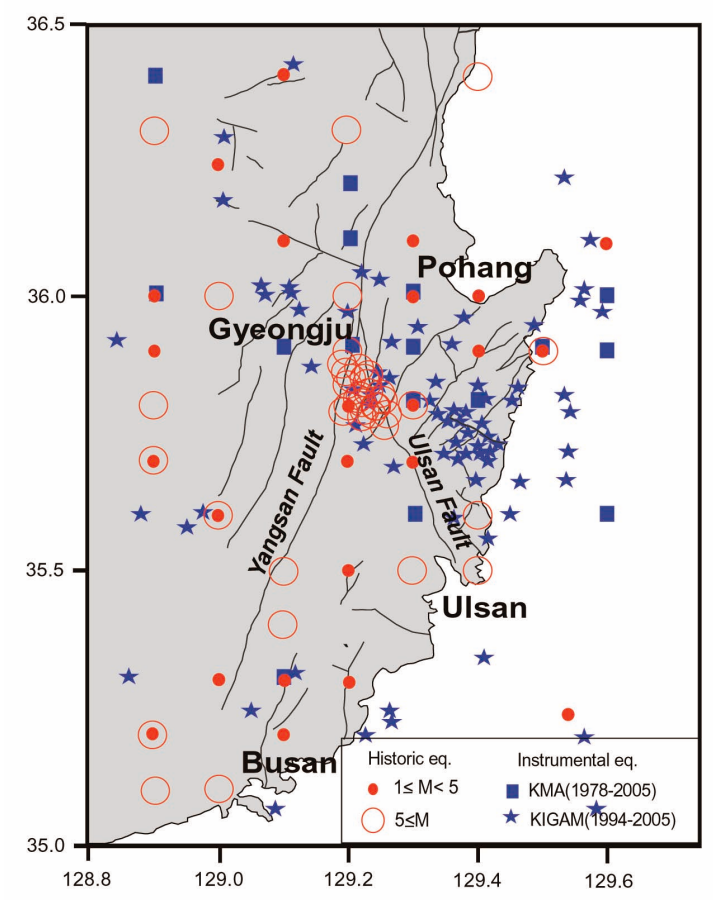

Fig. 3. Geological Structures and Epicenters of Earthquakes in the Southeastern Korean Peninsula

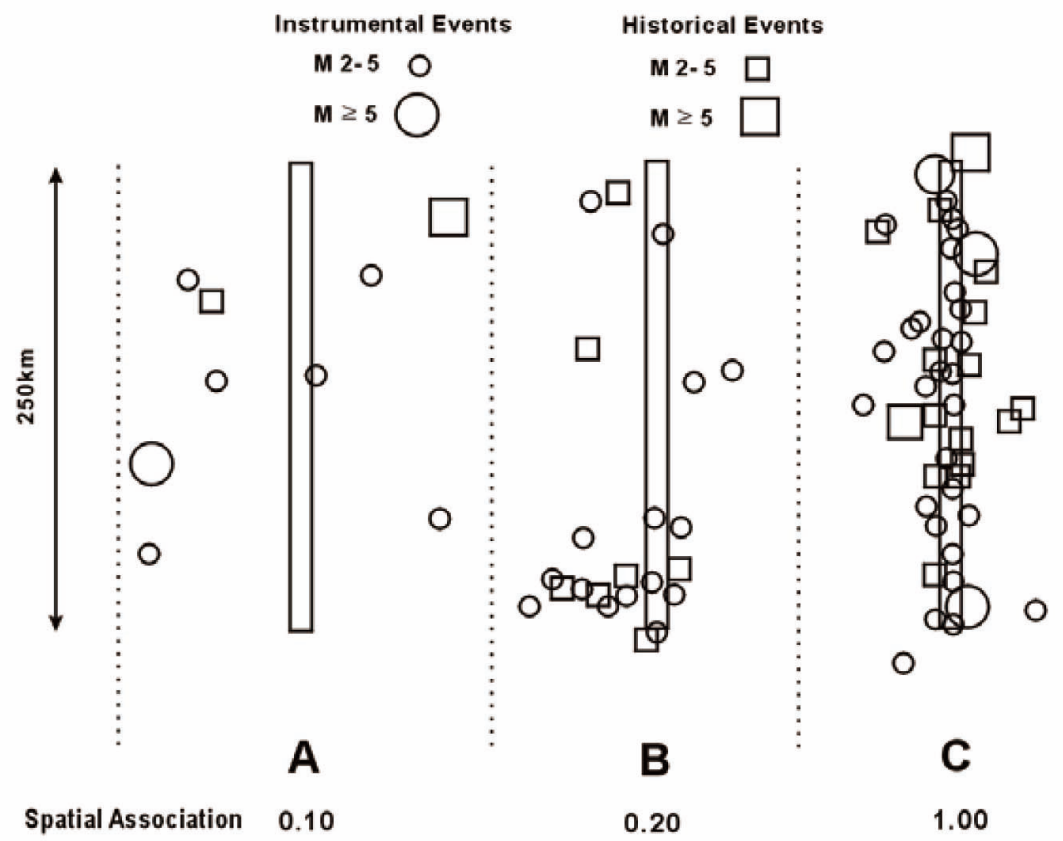

Fig. 2. Diagnostic Diagram to Estimate a Spatial Association between a Fault and Earthquakes [5] 


\subsection{Crustal Extent of the Fault}

It is most important to distinguish between tectonically induced seismogenic faults and non-tectonic phenomena that are not capable of producing significant earthquakes and vibratory ground motion such as landslides. This criterion is considered as one of relatively low weight because of the perception that a crustal-scale extent is not an exclusively sufficient condition for assessing seismogenic potential. However, because active faults would be expected to extend to seismogenic depths (10$20 \mathrm{~km}$ ), the crustal extent of a fault is in fact important in assessing the seismogenic potential of a fault. Most Quaternary faults in Korea are interpreted as having a tectonic origin in geological surveys, geophysical prospecting, and boring surveys, and are not evidence of non-tectonic landslides. And it also shows that the focal depth of earthquakes on the Korean peninsula is in the range of 10-20 km. Therefore, it could be considered that most of the Quaternary faults in Korea extend to seismogenic depth.

\subsection{Age of Faulting}

In Korea, age of faulting has been used as a criterion to make diagnoses of active faults in order to fulfill the regulatory criteria of 10CFR100 App. A and Reg. Guide 1.165 , which have been applied to Korea. Therefore, dating is a critical tool in assessing an active fault. Dating techniques can be grouped into three categories: numerical, relative dating, and correlation. Although numerical techniques are best, datable materials are often lacking. In such cases, relative dating or correlation techniques must be used. In Korea, because some of the Quaternary faults, close to the Wolsong nuclear power plant site, could be considered as active faults, it is critical that seismic hazard for nuclear power plants be carefully assessed. Therefore, dating techniques such as ESR, OSL, $\mathrm{Rb} / \mathrm{Sr}, \mathrm{K} / \mathrm{Ar},{ }^{14} \mathrm{C}$, and so forth have been applied to dating deposits and deformation of late Cenozoic age at several sites.

For example, if the maximum ESR age from a fault gouge is $380 \pm 30 \mathrm{ka}$, the OSL age is $68 \pm 8-92 \pm 22 \mathrm{ka}$ from the Quaternary terrace deposit [10]. Choi et al. [11] carried out a retrodeformation analysis based on stratigraphic correlation and OSL dates of colluvial deposits. The results revealed four events including three-time faulting during the latest Pleistocene at the Suryum fault. They suggested that the reactivation slip rates on the Suryum fault are $0.15-0.4 \mathrm{~mm} / \mathrm{yr}$ over the last $12,000 \pm 2000-2,800 \pm 200 \mathrm{yr}$ from the OSL age and might be related to a $\mathrm{Mw}$ 6-7 earthquake during the late Pleistocene. This study would divide the geological age into three ranks, Tertiary, Pleistocene, and Holocene, as basic criteria of faulting age to assess the capability of a fault. Although this given category of three ranks includes an age out of Quaternary time, it gives a basic category to define an age of faulting and there may be thought to be different type of ranks, such as Pleistocene, early- and late Holocene, or values of each weight by the judgments of experts according to relative weight.

\subsection{Tectonic Geomorphology}

Tectonic geomorphology is essential for complete paleoseismological investigation. The morphology of fault-generated mountain fronts and escarpments can indicate relative tectonic activity. In the past, it was difficult to assign reliable ages to geomorphic and tectonic features and it was nearly impossible to determine competing concepts of landscape evolution. During the past few decades, developments of many new techniques for determining the ages of landscape features, for assessing the mechanisms and rates of geomorphic processes, and for defining rates of crustal movement, have helped revitalize the field of tectonic geomorphology. It is now possible to quantify at a scale of millimeters how rapidly a given site is moving with respect to another and how those rates of relative convergence or divergence are partitioned among various faults. To quantify the active potential of lineaments, this study would divide the tectonic geomorphology into five ranks, very high, high, low, very low, and suspicious based on the characteristic features of a straight creep and steep slope of terrace, a cliff continuing on a terrace surface, streams and ridges bending, lineament continuing, and so on (Table 1). If a fault cross cuts the terrace of a higher rank, it would be estimated to be at the more active level.

\subsection{Relationship between Fault Slip and Tectonic Stress Regime}

An active fault would act under the current stress regime and the brittle slip of faults may be consistent with the current tectonic stress. Because earthquakes are an expression of the release of tectonic stresses, seismogenic faults are favorably oriented relative to tectonic stresses. Therefore, it is important to compare brittle fault slips with the current stress regime to evaluate whether the fault has acted on the current stress regime. In general, most of the Quaternary faults on the Korean peninsula show reverse movement with N-S striking dipping to the east (Fig. 4). As shown in Fig. 4(a), the right-lateral offset of stream and ridge is observed at Yugye-ri, Bogyeongsa area along the northern reach of the Yangsan fault. The fault dips to the east $\left(45^{\circ} \mathrm{SE}\right)$ with a reverse sense and cuts the lower-mid fluvial terrace. The latest fault event of Yugye-ri would have occurred during 2,400-2,000 yr BP [7]. It could be supposed that the faults might have acted on the maximum horizontal compressive stress of the E-W trend. The Quaternary faults discovered along the Yangsan fault are partially inharmonious with the current stress regime (Fig. 5). Ultimately, the probability of a relationship between the current stress by a focal 
Table 1. The Ranks and Certainty of an Active Lineament Based on the Terrace and Geomorphologic Phenomena [Summarized Reference 12]

\begin{tabular}{|c|c|c|c|c|}
\hline \multirow[b]{2}{*}{ Rank } & \multirow[b]{2}{*}{ Probability } & \multicolumn{3}{|c|}{ Feature } \\
\hline & & Terrace & $\begin{array}{c}\text { Mountains and/or Hills } \\
\text { (cliffs, streams and ridges bending) }\end{array}$ & Note \\
\hline A & Very High & $\begin{array}{l}\text { - A straight fresh cliff and } \\
\text { steep slope continue on the } \\
\text { same terrace surface lying } \\
\text { at different levels } \\
\text { - A straight cliff and steep } \\
\text { slope continue on several } \\
\text { terrace surfaces which are } \\
\text { of different ages }\end{array}$ & $\begin{array}{l}\text { - Fresh cliffs arranged in straight and } \\
\text { continuous pattern break the continuity of } \\
\text { the same geomorphic surface by separating } \\
\text { the level uniformly } \\
\text { - Streams and ridges bend to the same } \\
\text { direction systematically. The amount of } \\
\text { offset and the scale of the rivers are closely } \\
\text { correlated, or a topography formed by } \\
\text { faulting certainly can be seen }\end{array}$ & $\begin{array}{l}\text { - The direction of the lineament } \\
\text { makes a right or obtuse angle } \\
\text { with erosion scraps } \\
\text { - A lineament continuing well, along } \\
\text { which geomorphic surfaces lie at } \\
\text { different levels distinctly and } \\
\text { uniformly }\end{array}$ \\
\hline B & High & $\begin{array}{l}\text { - A straight fresh cliff and } \\
\text { steep slope, which didn't } \\
\text { erode, continue inferably } \\
\text { on the same terrace surface } \\
\text { lying at different level }\end{array}$ & $\begin{array}{l}\text { - Cliffs arranged in straight and continuous } \\
\text { pattern break the continuity of the same } \\
\text { geomorphic surface by separating the } \\
\text { level uniformly } \\
\text { - Streams and ridges bend to the same } \\
\text { direction systematically and clearly. } \\
\text { Moreover, } \\
\text { (1) The lineament is long } \\
\text { (2) The amount of offset and the scale of } \\
\text { the rivers are closely correlated, or a } \\
\text { topography, like shutter ridge, wind } \\
\text { gap, formed by faulting certainly, can } \\
\text { be seen, though the lineament is short }\end{array}$ & $\begin{array}{l}\text { - The direction of the lineament } \\
\text { makes a right or obtuse angle } \\
\text { with erosion scraps } \\
\text { - A cliff and steep slope face in } \\
\text { toward the general slope } \\
\text { - A lineament continuing well, along } \\
\text { which geomorphic surfaces lie at } \\
\text { different levels distinctly and } \\
\text { uniformly }\end{array}$ \\
\hline $\mathrm{C}$ & Low & $\begin{array}{l}\text { - An almost straight cliff and } \\
\text { steep slope continue on a } \\
\text { terrace surface, which is } \\
\text { partially indistinct }\end{array}$ & $\begin{array}{l}\text { - Cliffs are partially indistinct or intermittent } \\
\text { despite the elements arranged straight and } \\
\text { along which geomorphic surfaces lie at } \\
\text { different levels uniformly } \\
\text { - The amount of offset and the scale of the } \\
\text { rivers are not correlated, despite streams } \\
\text { and ridges bent to the same direction. } \\
\text { Moreover, } \\
\text { (1) Bending is not clear, though the } \\
\text { lineament is long. } \\
\text { (2) The lineament is short, despite ending } \\
\text { being clear }\end{array}$ & $\begin{array}{l}\text { - Direction of the lineament makes } \\
\text { an acute angle with erosion } \\
\text { scraps } \\
\text { - A lineament continuing well, along } \\
\text { which geomorphic surfaces lie at } \\
\text { different levels uniformly. But } \\
\text { partially indistinct }\end{array}$ \\
\hline $\mathrm{D}$ & Very Low & $\begin{array}{l}\text { - An indistinct cliff and steep } \\
\text { slope on a terrace surface } \\
\text { continue intermittently }\end{array}$ & $\begin{array}{l}\text { - Elements continue intermittently or are } \\
\text { indistinct, though they arrange themselves } \\
\text { in an almost straight pattern. If geomorphic } \\
\text { surfaces lie at different levels, the amount } \\
\text { of offset is not uniform } \\
\text { - The lineament is short, despite streams } \\
\text { and ridges bending to the same direction }\end{array}$ & $\begin{array}{l}\text { - Discontinuity of geomorphic } \\
\text { surfaces is not clear } \\
\text { - The lineament, which is in a } \\
\text { similar direction and inclination } \\
\text { to that of the cliff and steep slope } \\
\text { to erosion scarps and general } \\
\text { slope, continues intermittently }\end{array}$ \\
\hline $\mathrm{E}$ & Suspicious & $\begin{array}{l}\text { - No cliff and steep slope on } \\
\text { a terrace surface }\end{array}$ & $\begin{array}{l}\text { - An obscure cliff, eroded well, cols and } \\
\text { other elements continuing intermittently }\end{array}$ & $\begin{array}{l}\text { - Discontinuity of geomorphic } \\
\text { surfaces is obscure } \\
\text { - The lineament, which is in a } \\
\text { similar direction and inclination } \\
\text { to that of the cliff and steep slope } \\
\text { to river cliff and general slope, } \\
\text { continues intermittently }\end{array}$ \\
\hline
\end{tabular}




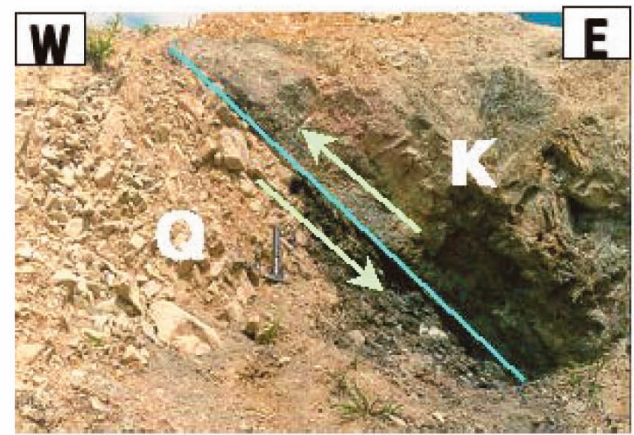

(a)

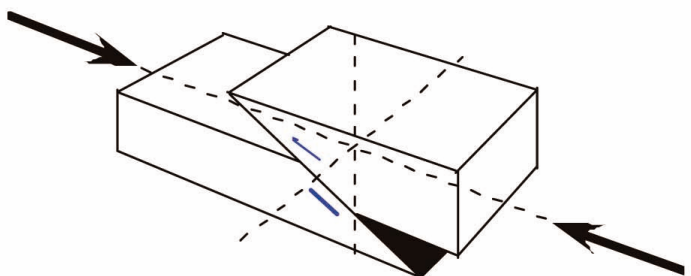

(b)

Fig. 4. (a) The Quaternary Fault at Yugye-ri. A Reverse Fault is Developed along the Contact among Highly Fractured Volcanic Rocks (K) and Quaternary Deposits (Q), (b) Diagram of the Reverse Slip Faulting

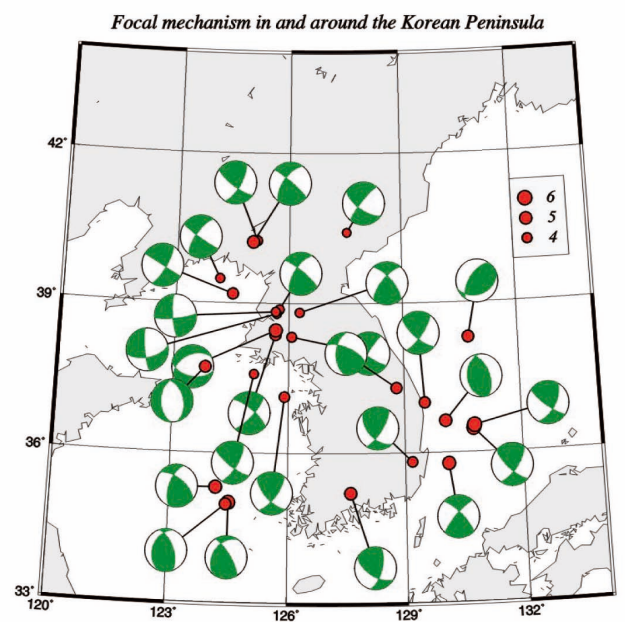

(a)

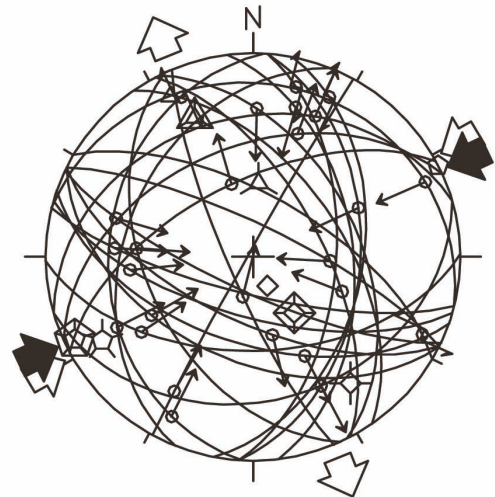

(b)

Fig. 5. The Focal Mechanisms Analyzed from Earthquake Data. (a) Epicentral Distribution (Solid Circles) and Fault Plane Solutions for 27 Major Events with $\mathrm{Mw} \geq 4$ in and around the Korean Peninsula (1936-2004) [13], (b) Focal Mechanism Analysis of 11 Earthquakes (1999-2004) in Gyeongju Area [14]

mechanism and the brittle slip from the Quaternary faults in the SE Korean peninsula could be estimated through a fault slip analysis (Fig. 6). In Fig. 6, large arrows show the directions of maximum or minimum horizontal stress, and polygons, boxes and circles indicate the maximum, intermediate and minimum principal stress axes, respectively, on lower hemisphere projections.

\subsection{Multiple Reactivations of the Fault}

As mentioned previously, the recognition of reverseslip Quaternary faults is rather common along the east coastal line near the Wolsong NPP site in the SE part of the Korean peninsula. These Quaternary faults show strong evidence of multiple fault reactivations, which act on normal-slip along the Cretaceous-Tertiary boundary and reverse-slip at the Quaternary deposits. There is evidence of supposed fault striations that give further evidence of multiple episodes on the same fault plane along the Yangsan fault in Korea (Fig. 7) [15]. This geological evidence for multiple reactivation of a fault indicates that the fault has experienced several brittle slips during different geologic times with reference to large earthquakes. Therefore the evidence of multiple reactivations of a fault could be used as a good diagnostic indicator for evaluating the future seismogenic potential of a fault. 


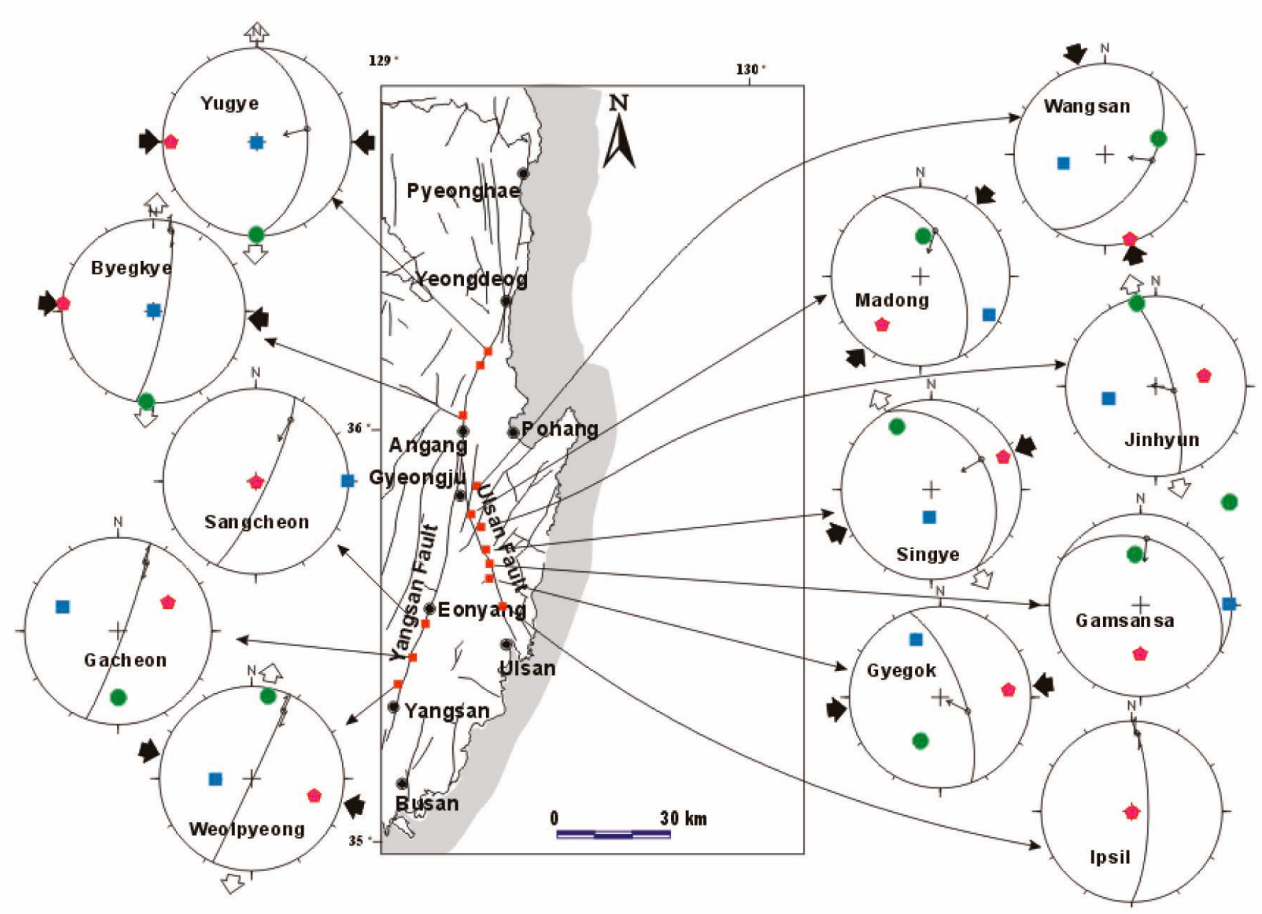

Fig. 6. The Fault Slip Analyses Obtained from 12 Outcrops of the Quaternary Faults Discovered along the Yangsan and Ulsan Fault in SE Korea.

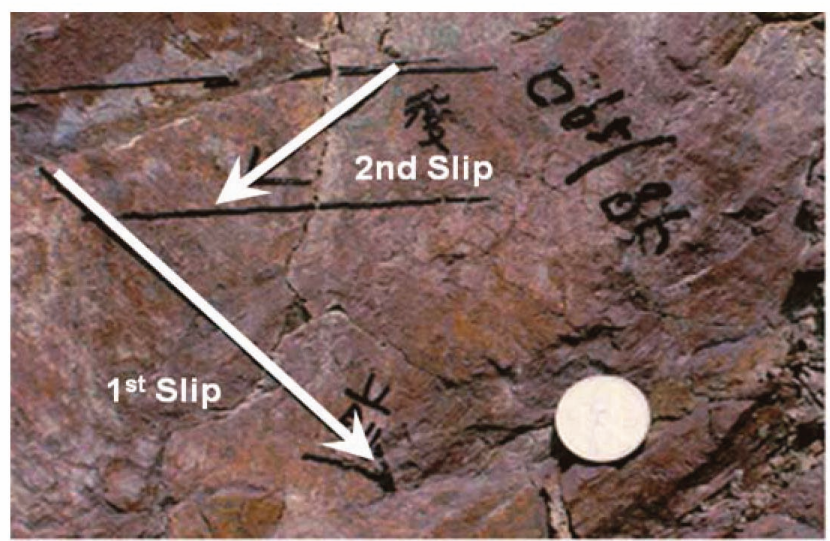

Fig. 7. Superposed Fault Striations for Determining the Relative Chronology between Fault Slips. This Shows that Several Quaternary Faults in Korea Performed as Normal Slips along the Cretaceous-Tertiary Boundary, and after that They were Reactivated as Reverse Slips during the Quaternary Period

\section{PROCEDURE AND DISCUSSION}

The Upcheon fault, which is located about $1.5 \mathrm{~km}$ from the Wolsong nuclear power plant, is strike/dip of $\mathrm{N} 15^{\circ} \mathrm{E} /$ $45^{\circ} \mathrm{SE}$, and a trench survey, geophysical prospecting, and core drilling were carried out to interpret the trace length and paleoseismological characteristics. The trace length of the fault was measured at about $1.5 \mathrm{~km}$ on the ground surface. Although the ESR age obtained from the fault gouge was $1,344 \pm 79 \mathrm{ka}$, this might not be considered the latest activity of the fault movement. The age of a lower 
Table 2. Earthquake Magnitude of the Upcheon Fault Estimated from the Fault Source Parameters

\begin{tabular}{|c|c|c|c|}
\hline Approaches & Fault parameters & Range of $\mathrm{M}$ & Average $\mathrm{M}$ \\
\hline Surface Rupture Length & $1.5 \mathrm{~km}$ & $3.70-6.44$ & 5.36 \\
\hline Maximum Displacement & $1.5 \mathrm{~m}$ & $6.82-7.08$ & 6.98 \\
\hline Average Displacement & $1.5 \mathrm{~m}$ & 7.07 & - \\
\hline Rupture Area & $18 \mathrm{~km}^{2}$ & $5.13-5.51$ & 5.31 \\
\hline Seismic Moment & $1.5 \mathrm{~km} / 4 \mathrm{~m} / 10 \mathrm{~km}$ & $6.14-6.40$ & - \\
\hline Moment Release Rate & $100 \mathrm{ka}$ & 6.46 & - \\
\hline
\end{tabular}

marine terrace $(20-25 \mathrm{~m})$ cut by faulting was interpreted to be $80 \mathrm{ka}$ and $125 \mathrm{ka}$ (MIS 5e) by OSL dating and tephra correlation, respectively. And the age of a middle terrace discovered at the outcrop of the Upcheon fault was estimated to be $214 \mathrm{ka}$ (MIS 7) by tephra correlation [16]. According to the trench survey, the amount of dislocation of the Upcheon fault varies 238-709 $\mathrm{cm}$ by the key beds (discontinuity, colluvial wedge, and bedding plane); however, the result of synthetic judgment indicates that the Upcheon fault experienced at least three events of faulting and an estimated net-slip of $1.5 \mathrm{~m}$ during the last faulting time.

In the deterministic method, if the Upcheon fault is active by determination of the faulting age, it is necessary to evaluate the size of earthquake that can occur along the fault for the seismic design of a nuclear power plant. In this case, the fact that the fault is active was determined only by dating from geological material and the probability of a seismogenic event, which was 1.0 (100\%). However, it is not easy to define the coseismic surface rupture length based on the surface fault geometry alone because the geology in Korea is relatively old in comparison with that of active areas. Moreover, because it is also difficult to obtain material suitable for dating prehistoric earthquakes, it is not easy to evaluate the recurrence interval and the slip rate of faulting. On the assumption that the Upcheon fault is active, and that the probability of seismogenic potential is assessed to be 1.0 , in this study, five approaches were used to scale earthquake size, which include: the fault rupture length, rupture area, fault displacement, seismic moment calculation and moment release rate methods [17]. The maximum earthquake was estimated from the empirical relations between the earthquake size and fault parameters based on the source parameters of the Upcheon fault (Table 2).

These results indicate that the different paleoearthquakes are attributed to various factors of over- and underestimation in evaluating the earthquake potential, and the results may not fully identify the detailed geometry and dynamics of the faults. Moreover, because the Upcheon fault is considered to be seismogenic with a probability of 1.0, the earthquake size of the Upcheon fault is too conservative and uncertain for the seismic design of nuclear power plant.

To resolve this type of uncertainty and apply the probabilistic fault activity to the probabilistic seismic hazard analysis, this study suggests new criteria and a quantitative diagnostic procedure that could estimate whether a fault is capable of generating earthquakes in the near future. The procedure for calculating the probability that a fault is seismogenic is as follows. (1) Determine the relative weight assigned to each criterion, (2) judge the probability of a seismogenic potential based on the geological and seismological data, (3) calculate the probability of seismogenic potential, multiply by the relative weight of each criterion; (4) these products are then summed and divided by the sum of the relative weight of each criterion (Table 3 ). In applying this method, the additional criteria and the different relative weights as determined by experts would be considered for probabilistic seismic hazard analysis.

\section{CONCLUSIONS}

To assess the seismic hazard of a nuclear power plant site it is most important to identify whether the fault is active. If the fault is of tectonic and seismogenic origin, capable of producing a large earthquake, the fault should be considered as a seismic source when determining seismic design. Because it can be determined only by age dating whether a fault is active or not in the deterministic method, it is necessary to evaluate the uncertainty in assessing the probabilistic seismic hazard for a nuclear power plant. This study suggests a procedure and criteria for assessing the probability of seismogenic potential of a 
Table 3. Criteria and Procedure for Assessing the Seismogenic Potential of a Fault

\begin{tabular}{|c|c|c|c|c|}
\hline \multicolumn{2}{|c|}{ Criterion } & Weight & Probability & Product \\
\hline \multicolumn{2}{|c|}{ Fault with historical rupture } & 9.0 & A & $9.0 \times \mathrm{A}$ \\
\hline \multicolumn{2}{|c|}{ Association $(\mathrm{M}>5)$} & 7.0 & $\mathrm{~B}$ & $7.0 \times \mathrm{B}$ \\
\hline \multicolumn{2}{|c|}{ Association $(\mathrm{M}<5)$} & 6.0 & $\mathrm{C}$ & $6.0 \times \mathrm{C}$ \\
\hline \multicolumn{2}{|c|}{ Crustal Extent of fault } & 2.0 & $\mathrm{D}$ & $2.0 \times \mathrm{D}$ \\
\hline \multirow{3}{*}{ Age of Faulting } & Holocene & \multirow{3}{*}{8.0} & \multirow{3}{*}{$\mathrm{E}$} & \multirow{3}{*}{$8.0 \times \mathrm{E}$} \\
\hline & Pleistocene & & & \\
\hline & Tertiary & & & \\
\hline \multirow{5}{*}{$\begin{array}{c}\text { Tectonic } \\
\text { Geomorphology }\end{array}$} & A & \multirow{5}{*}{7.0} & \multirow{5}{*}{$\mathrm{F}$} & \multirow{5}{*}{$7.0 \times \mathrm{F}$} \\
\hline & B & & & \\
\hline & $\mathrm{C}$ & & & \\
\hline & $\mathrm{D}$ & & & \\
\hline & $\mathrm{E}$ & & & \\
\hline \multicolumn{2}{|c|}{ Brittle Slip/Stress Regime } & 4.0 & G & $4.0 \times \mathrm{G}$ \\
\hline \multicolumn{2}{|c|}{ Multiple Reactivation } & 2.0 & $\mathrm{H}$ & $2.0 \times \mathrm{H}$ \\
\hline \multicolumn{4}{|c|}{ Sum of Products } & $\mathrm{S}$ \\
\hline \multicolumn{4}{|c|}{ Sum of weights } & 45.0 \\
\hline \multicolumn{4}{|c|}{ Probability (Seismogenic) } & $\mathrm{S} / 45.0$ \\
\hline
\end{tabular}

fault. In the procedure and criteria suggested, the relative weight and probability may depend on field evidence and expert judgment. It is expected that this method can be used for probabilistic seismic hazard analysis on the Korean peninsula.

\section{ACKNOWLEDGEMENTS}

I greatly value the careful reviews undertaken by three anonymous reviewers. This work was supported by the radioactive waste management program of the Korea Institute of Energy Technology Evaluation and Planning (KETEP) in a grant funded by the Ministry of Knowledge Economy, Republic of Korea (No. 201017102002C).

\section{REFERENCES}

[1] A. Okada, K.. Takemura, M. Watanabe, Y. Suzuki, and J.B. Kyung, "Trench excavation survey across the Yangsan and Ulsan fault systems in the southeastern part of Korean peninsula", Transactions, Japanese Geomorphological Union, 22(3), 287-306 (2001)

[2 ] J.B Kyung, K. Lee, A. Okada, K. Takemura, M. Watanabe, Y. Suzuki, and K. Oike, "Active fault study in the central part of the Yangsan fault, southeastern part of Korea", Tectonic Evolution of Eastern Asian Continent, Geological Society of Korea, 33-38 (1997).

[ 3 ] U. Chwae, D.Y. Lee, B.J. Lee, C.R. Ryoo, P.Y. Choi, S.J. Choi, D.L. Cho, J.Y. Kim, C.B. Lee, W.S. Kee, D.Y. Yang, I.J. Kim, Y. Kim, J.H. Yoo, B.G. Chae, W.Y. Kim, P.J. Kang, I.H. Yu, and H.K. Lee, "An investigation and evaluation of capable fault, southeastern part of the Korean Peninsula", KIGAM Research Report KR-98(c)22, Korea Institute of Geology, Mining and Materials, Daejeon, 301p, (in Korean with English abstract) (1998)

[4 ] KHNP (Korea Hydro and Nuclear Power Co.), "Establishment of techniques for assessment of Neotectonics for seismic safety in Korean peninsula (Final Report)", KEPRI/ R06SF25, 685p. (in Korean with English abstract) (2009)

[ 5 ] K.L. Hanson, K.I. Kelson, M.A. Angell and W.R. Lettis, "Techniques for Identifying Faults and Determining Their Origins”, NUREG/CR-5503, U.S. Nuclear Regulatory Commission (1999).

[6] K. Lee, "Historical Earthquake data of Korean", The Journal of Geophysical Society of Korea, 1, 3-22 (1998)

[7] J.B. Kyung, "Paleoseismological characteristics of the Yangsan and Ulsan faults since the Late Quaternary time", In: Kee, W.S., Kim, Y.H. and Song, K.Y. (eds.), Quaternary Tectonics of Southeastern Korea, The 5th Symposium of Geology of Korea, KIGAM, 45-55. (in Korean with English abstract) (2007)

[8 ] K. Lee and S.H. Na, "A study of microearthquake activity along the Yangsan fault", Journal of Geological Society of Korea, 19, 127-135 (1983)

[9 ] K. Lee, B.I. Jeong, Y.H. Kim, and S.J. Yang, “A geophysical study of the Yangsan fault area", Journal of Geological Society of Korea, 20, 222-240 (1984)

[10] KINS (Korea Institute of Nuclear Safety), “Development of technology and background for seismic safety evaluation (Final Report)", KINS/CR-255, Vol.1, 746p. (in Korean with English abstract) (2003)

[11] Sung-Ja Choi, Duk-Geun Hong, Weechan Chwae, Yun Goo Song, Changryol Kim and Taekmo Shim, "Retrodeformation analysis of the Quaternary fault in the southeastern Korean Peninsula", Gondwana Research, doi:10.1016/j.gr.2009. 07.008 (2009).

[12] D. Inoue, M. Yanagida, W.H. Choi, and C.J. Chang, "Stratigraphy of the marine terraces along the East coast in Korea by means of the loess-paleosol sequence and Japanese tephra", Proceeding of 2002 Annual Meeting of Geological Society of Korea, p.81 (2002)

[13] Shuanggen Jin and Pil-Ho Park, "Tectonic activities and deformation in South Korea constrained by GPS observations", International Journal of Geology, Issue 2, 1, 11-15 (2007)

[14] J.-C. Park, W. Kim, T.W. Chung, C.-E. Baag, and J.H. Ree, "Focal mechanism of recent earthquakes in the Southern Korean Peninsula", Geophys. J. Int., 169, 1013-1114 (2007)

[15] C.J. Chang, "Structural characteristics and evolution of the Yangsan fault, SE Korea", Ph.D. Thesis, Kyungpook National University, Daegu, Korea, 259p. (in Korean with 
English abstract) (2001)

[16] KHNP (Korea Hydro and Nuclear Power Co.), "Development of technology of advanced seismic assessment of NPP sites (Final Report)", KEPRI/01NS17, 860p. (in Korean with English abstract) (2004)
[17] KEPRI (Korea Electric Power Research Institute), "Evaluation of maximum potential earthquake for nuclear power plant sites (Final Report)", KINS/GR-335, KEPRI/ TR.E08.C2006.225, 531p. (in Korean with English abstract) (2006) 